\title{
Copyright ownership of e-learning and teaching materials: Policy approaches taken by UK universities
}

\author{
Elizabeth $\operatorname{Gadd}^{1}$ (D) Ralph Weedon ${ }^{2}$
}

Received: 12 September 2016 / Accepted: 26 January 2017/Published online: 4 February 2017

(C) The Author(s) 2017. This article is published with open access at Springerlink.com

\begin{abstract}
Investigates whether and how UK university copyright policies address key copyright ownership issues relating to printed and electronic teaching materials. A content analysis of $81 \mathrm{UK}$ university copyright policies is performed to understand their approach towards copyright ownership of printed and e-learning materials and performances; rights on termination of contract; rights of non-staff contributors. Crosstabulations are performed with the mission group and age of copyright policy. $90 \%$ of copyright policies address teaching materials explicitly. Fewer universities (77\%) claim ownership of internal teaching materials than e-learning materials (84\%). Only $20 \%$ address performance rights, $46 \%$ address rights of non-employees, and $44 \%$ address rights on termination of contract. Russell Group universities have more liberal copyright policies around ownership of teaching materials than newer universities. Recent copyright policies are more liberal than older policies. Recommends that UK universities work with academic staff to address key copyright policy issues in a way that balances the rights of both parties. This the first empirical study of UK university copyright policy approaches towards the ownership of teaching and e-learning materials.
\end{abstract}

Keywords Copyright $\cdot$ Intellectual property $\cdot \mathrm{MOOC} \cdot$ E-learning $\cdot$ Open educational resources $\cdot$ Higher education

Elizabeth Gadd

e.a.gadd@lboro.ac.uk

Ralph Weedon

ralph.weedon@strath.ac.uk

1 Research Policy Manager, Loughborough University, Loughborough LE11 3TU, UK

2 Information Management Division, University of Strathclyde, 16 Richmond St, Glasgow G1 1XQ, UK 


\section{Introduction}

More and more universities are investing in technology-enabled learning. Developments range from the simplest of efforts to make lectures notes available on web pages, to advanced multimedia, interactive online courses. Many studies pertaining to copyright and e-learning focus on the complex issues of obtaining copyright permission from third-parties to re-use content in these developments (see Halme and Somervuori 2012), and how to manage access and use of the resulting products through licensing (Cheverie 2013). However, for academics working in Higher Education Institutions there is an equally pressing consideration, namely, who owns the rights in any elearning materials that they produce? This is particularly pertinent to the development of the global Open Educational Resources (OER) movement (Matkin 2006) and Massive Open Online Course (MOOC) platforms (BIS 2013), which increase the capacity for maximum re-use of e-learning materials whilst at the same time providing income-generating potential for the rights-holder(s). Universities are keen to protect any investment they make in such initiatives by asserting their rights over the resulting product (Cate et al. 2007; HEFCE 2006). However academics, already wary about the commodification of higher education, are becoming increasingly nervous about any attempts by universities to commercialise what they see to be their intellectual property (Davies 2015). As Literat (2015) writes "the commercial agreements between MOOCs and educational institutions often conflict with the common institutional policy approach that grants intellectual property rights to faculty who develop the course." Thus the issue of who owns the rights in teaching materials has become the subject of much debate (see Pila 2010; Rahmatian 2014; Blanchard 2010).

In the UK, the Copyright, Designs and Patents Act 1988 (CDPA) states that "where a literary, dramatic, musical or artistic work, or a film, is made by an employee in the course of his employment, his employer is the first owner of any copyright in the work subject to any agreement to the contrary" (s.11(2)). US legislation takes a similar approach (discussed below). Some claim that this applies to academic employees and therefore the copyright in teaching materials belong to universities (Strauss 2011) whilst others claim that the academic/university relationship is atypical and therefore the Act would not apply (Pila 2010; Rahmatian 2014). Either way, the legislation alone does not address all the pertinent issues around the rights ownership of e-learning materials. For example, what happens when an employee leaves the organisation, and who owns the rights in e-learning materials part-developed by non-employees, or even students? It is therefore important that universities have effective copyright policies that address these issues (Lape 1992).

This paper performs a review of the literature to identify the key issues relating to the ownership of copyright in e-learning materials and then reports on a content analysis of 81 UK universities copyright policy documents with a view to answering the following research questions:

- Do UK university copyright policies address ownership of copyright in e-learning materials?

- If so, is there a difference between their approach towards ownership of internal teaching materials and e-learning materials? 
- Do UK university copyright policies address key issues pertaining to the ownership of e-learning materials?

- Is it possible to identify any trends in policy approaches by examining the differences between older and newer policies?

- Does the nature of a university as defined by their 'mission group' affect their approach towards the ownership of teaching and e-learning materials?

Recommendations are then made for universities with regards to the development of policy approaches to the copyright ownership of e-learning materials in the UK.

\section{Literature review: The key copyright issues for teaching materials in UK HE}

\subsection{Conflicting sector guidance as to who owns copyright in teaching materials}

Commentators on the copyright ownership of teaching materials produced by UK academics tend to fall into one of three camps: those arguing that academics either do, or should, own the rights; those arguing that universities do; and those that conclude that the situation is unclear or circumstance-dependent.

Not surprisingly, organisations supporting academic staff such as the University and College Union (UCU) tend to take the position that academics own the rights, and organisations supporting universities, such as the Higher Education Funding Council for England (HEFCE), take the view that universities own the rights. Interestingly, the positions of both of these groups have polarised significantly over the last fifteen years. Thus in 1999 the predecessor of the UCU, the Association of University Teachers (AUT) created a Guide to Intellectual Property (AUT 1999) which stated that, under law, the rights in teaching materials "belong" to the institution as employer. The later UCU Post-92 Model contract of employment (UCU 2006) took the same view. Despite this, the AUT Guide (1999) recommended that "authors should seek to retain copyright" in "material created directly for teaching, especially where it is for selfpaced or distance learning programmes." However, a more recent statement on intellectual property rights from the UCU refrains from asserting the institutional ownership of teaching materials, instead claiming that the situation is "complex" (UCU, [n.d]). It suggests that "institutions should... negotiate policies, the principal objectives of which ensure that [authors] should retain copyright in material produced during the course of their duties, allowing in some cases free use for teaching purposes within the employing institution" (UCU, [n.d]).

In a similar way, copyright guidance for universities has also shifted over time. In 1998, the HEFCE-funded Joint Information Systems Committee (Jisc) created some Copyright Guidelines with the Teaching and Learning Technology Programme (Jisc/TLTP, 1998) to provide "pointers towards good practice in the development of computer-based materials for higher education". The Guidelines recognised that in practice universities often rescinded copyright in favour of academic ownership. Even so, they stressed that "this is just a convention and should university authorities be so minded, they could choose to acquire the copyright in literary works created by academics in the course of their employment, by virtue of being the employer." Almost 
two decades later, after a period of rapid OER development, the Jisc moved beyond suggesting that universities could acquire the copyright in literary works and recommended that they should. The 2006 guidance for senior university managers on Intellectual property rights in e-learning programmes prepared by Jisc in partnership with the Higher Education Funding Council for England (HEFCE) claimed that:

\section{HEIs should own the IPR [Intellectual Property Rights] in the e-learning mate-} rials created by their staff, and contracts of employment should make this explicit. This also applies to freelance and, where agreed by them, to student creators. (HEFCE 2006).

However, it does concede that "lecture notes, as distinct from formal course/module handouts and learning materials, are generally regarded as the property of the lecturer, often as a matter of custom and practice" and that staff also "own the performers' rights in any video or other recording of their own lectures or presentations."

Thus, the guidance around the ownership of copyright in e-learning materials has seen a slow divergence over time. What began as a general acceptance that the rights belonged to the employing university but were relinquished through custom and practice, has diversified into a situation where universities are being encouraged not to relinquish these rights and the unions are responding with a question as to whether universities owned them in the first place.

\subsection{Confusion arising from a global debate affected by different legal and cultural jurisdictions}

Of course, while the scholarly debate on this issue is global, it is very much affected by the legal and cultural jurisdictions in which scholars are based. In the UK, commentators tend to fall into the first camp: the academics own the rights. Legal scholars Pila (2010) and Rahmatian (2014) both argue using (mainly UK) case law that academics are the rightful owners of intellectual property in scholarly works and teaching materials. However, even disregarding the legislation, Pila states, "my own view is that whatever the legal position, a university ought never to claim ownership of the copyright in its employee academics' lectures and research, nor of their inventions". Rahmatian (2014), on the other hand, does concede that "in law, the universities are in a better position to lay claim to copyright in teaching materials than to copyright in scholarly works." Davies (2015) studied UK universities copyright policy approaches towards the ownership of teaching materials as an indication of the degree to which universities support the concept of academic freedom. He concludes that "in many [UK universities], academic outputs, especially those relating to teaching, have already fallen within the entrepreneurial models of higher education and have become potentially saleable products to be owned and exploited by universities as they see fit." In response, he argues that UK academics should fight to retain the rights to their intellectual property, or "risk reduced opportunities to change employer and, at the extreme, provide their existing employer with the wherewithal to make significant elements of their job redundant."

In the US there is a strong lobby for the academic ownership of teaching materials, principally due to the powerful tradition of a 'teacher exception' to their 'work for hire' legislation. 'Work for hire' is the US equivalent of s 11(2) of the CPDA and is 
enshrined in Title 17, of the US Copyright Act (1976). It states, "In the case of a work made for hire, the employer or other person for whom the work was prepared is considered the author for purposes of this title, and, unless the parties have expressly agreed otherwise in a written instrument signed by them, owns all of the rights comprised in the copyright."

The teacher exception tradition grew out of common-law copyright (Centivany 2011) and was largely unquestioned both by the courts and academia until relatively recently (McSherry 2001). This does not mean it has gone unchallenged and the 1976 act "may arguably have removed the teacher exception sub silentio" (Longdin 2004). There is however case law to support the exception (e.g., Williams vs Weiser (1969) and Weinstein vs University of Illinois (1987)). Lape's (1992) seminal paper argued that "to the extent that the exception ever existed, it continues to exist" and it should be preserved "in order to protect the parties' expectations". However, McSherry (2001) asserts that the exception rests on 'a shaky foundation' and that "copyright ownership of lecture materials remains an open question."

Other US authors have also become less certain about this over time and many now fall into the second camp where the university is seen as the rightful owner. Indeed, a series of studies of US Research University copyright policies reported on by Kromrey et al. (2007) showed that the number of policies referring to 'work for hire' legislation increased from $9 \%$ in 1992, to $26 \%$ in 2002 and $57 \%$ in 2005. Klein (2005) claims that due to the investment online courses require, the university should be the ultimate rightsholder. Despite this, he encourages academics to negotiate certain moral and economic rights, such as creative credit; right to reproduce and revise; future use, and royalties if commercialised. Gertz (2006) suggests that to avoid ambiguities universities should own the rights to faculty-created works, and licence them to academic staff. Strauss (2011) takes a stronger line and argues that as "the scope of a professor's employment includes the production of scholarly articles and teaching materials" then "every work the professor creates and publishes is automatically a work made for hire, owned by the university".

\subsection{The shared ownership interests of universities and academics in e-learning materials}

In the third camp are those authors who can see both sides of the argument. Many of these claim that "the answer to who owns the [intellectual] property depends on the condition in which it was produced" (Rhoades 1998). Loggie et al. (2006) suggests that those conditions might include whether the teaching materials were commissioned, whether the authors were compensated, and whether there was significant use of university resources in their creation. Monotti and Rickeston (2003) drew similar conclusions, with the addition that "the classification of the originator" and "the material in respect of which such claims were advanced" were also factors. Other commentators, such as Longdin (2004) and Loddington et al. (2006) point to the fact that whilst under law universities appear to have a strong claim to copyright ownership in teaching materials, their long history of waiving copyright means that the situation is by no means certain.

Most of the commentators in this camp recognise that there is still a long way to go before these issues are satisfactorily concluded, but that this will only happen if both parties enter the negotiating arena recognising they all have something to gain. 
Blanchard (2010) suggests that the "faculty-institution relationship is a symbiotic one" and what benefits one, benefits the other. Bowrey (2002) and Kromrey et al. (2007) encourage academics and universities to work together to fight the increasing commercialisation of scholarly works where publishers are the only real winners. Longdin (2004) reminds us that:

Authors are in the end as mobile as their works and will gravitate to institutions where online copyright issues are sensitively handled. What is needed is the transfer of sufficient rights to accommodate course management without sacrificing mobility and academic freedom.

The corollary of not coming to agreement is a situation where the writing of online courses is contracted out to third-parties - in some cases PhD students (Noble 1998), or finding that "the bolder spirits among [teaching staff and commercial providers] set up shop together outside the institution" (Longdin 2004). Neither of these options benefits either party.

Indeed, the literature suggests that coming to an amicable agreement around the ownership of rights in teaching materials might not be as challenging as the debate implies. A survey of academic staff at Monash University in 1997 performed by Monotti and Rickeston (2003) surprisingly found that respondents showed "a considerable degree of willingness to share ownership of both research and teaching materials, or to consider this option (almost 90 per cent altogether), thus removing the possible conclusion that academic creators believe universities should have no rights in this material."

Similarly, the Jisc-funded Rights \& Rewards (R\&R) project (Bates et al. 2007) utilised a methodology devised by the 2003 Rights Metadata in Open Archiving (RoMEO) project (Gadd et al. 2003) to understand how academics wanted to protect any outputs they might make available in an open electronic environment. The R\&R project focussed on e-learning materials whilst the RoMEO project focussed on research outputs. Interestingly $28 \%$ of R\&R respondents thought the institution owned the copyright in their e-learning materials compared to $61 \%$ of RoMEO respondents who believed the academic owned the copyright in their research outputs. In total, $51 \%$ of $\mathrm{R} \& \mathrm{R}$ respondents expected their university to be attributed when copies of elearning materials were made.

These findings are interesting and demonstrate that despite the strong rhetoric around academic ownership of intellectual property, there is, amongst academics, an understanding of the legitimate interests of the university in e-learning materials.

\subsection{Ownership issues not resolved by section 11(2) of UK copyright law}

Whether or not the provisions of section 11(2) of the CDPA (or indeed the USA's work for hire legislation) do apply to works produced by academics, its effect on e-learning materials is limited in other ways.

i) Types of content

The first is that it the UK legislation only covers "literary, musical, artistic works or films" made in the course of employment. This would cover most internal teaching 
materials, however, a MOOC or OER may also contain other copyrightable or even patentable works such as sound recordings, broadcasts, performances, software, or designs (Porter 2013). Perhaps the most prevalent of these in online learning offers is performances. Indeed, the primary purpose of lecture capture is to "copy" performances and a recent survey of US professors offering MOOCs by The Chronicle of Higher Education found that $97 \%$ provided "original videos" as part of their courses (Kolowich 2013). Unlike other works made in the course of employment, unless there is an agreement to the contrary, academics would be the legal rights-holders in any performances they undertake. It is not clear if the US work-for-hire legislation contains this discrepancy as it merely refers to 'a work'.

\section{ii) Non-employee creators}

The second limitation of s.11(2) is that academic employees are not the only actors involved in the creation, and publication, of e-learning materials. Others might include the university as commissioner of the course, academic staff from other institutions, bought-in consultants, external software providers, and even students (Porter 2013). As s.11(2) only applies to employees, the contributions of such non-employees to elearning materials would need to be handled separately. Zhang and Carr-Chellman (2006) also suggest that non-academic employees (such as IT staff and instructional designers) may have a different status with regards to the ownership of e-learning materials as it would be more difficult to argue that they were not creating such materials "in the course of employment".

\section{iii) Rights on termination of contract}

Thus, even if UK universities were to rely on s.11(2) to claim copyright in e-learning materials, there would still be a need for agreements with their creators to address such issues. Where universities do not assert s.11(2) one of the key issues relating to the development of e-learning materials is the mobility of their academic creators (Zhang and Carr-Chellman 2006). Academic employees rarely remain at one institution for the whole of their careers. Questions are therefore raised as to what happens to the teaching materials when the author is no longer at the university. If the university claims ownership or at least refuses to permit an academic to take a copy with them, this might constitute a Restraint of Trade, invoking legislation that protects an individual's rights to continue practising their trade when they move from one employer to another (McCann 2014). If the university claims ownership but licenses rights back to the academic - do the rights continue when they leave the university? If the university relinquishes ownership but claims a licence to reuse the teaching materials, does this continue beyond the life of the employment contract? Finally, if the academic is the designated rightsholder and as such has asserted their moral rights in, say, a videoed performance, what happens when the university wants to make subsequent changes to it?

Secker and Morrison (2016) are of the opinion that whilst the copyright in most digital teaching materials belongs to the employer,

many universities aim to strike a balance between ensuring that staff have the freedom to retain ownership of their teaching materials while giving the university the right to use teaching materials in the future, in any manner of teaching. However, 
there is inevitably a tension between lecturers wanting to use their teaching materials when they move to other institutions and the institution wanting to continue to exploit content, potentially exclusively.

This is particularly the case where such content is developed collaboratively by a team. Indeed, the HEFCE guidance (2006) suggested a model contract clause stating that academics may negotiate with their former employer to allow continued access to the e-learning materials, "provided that the use of the e-learning materials does not damage the exploitation of the materials by [the Institution] or prejudice in any way the interests of the Institution". Of course, if these issues are not resolved, an academic could find themselves facing a civil action for copyright infringement, resulting in a fine - or in extreme cases, imprisonment. However, in practice most disputes are resolved out of court (e.g., Newman 2010).

To summarise, the limitations of UK copyright law and its historical application (or non-application) to the ownership of rights in e-learning materials in UK universities, alongside conflicting guidance from external organisations such as the UCU and Jisc, leaves both universities and academics with an amount of uncertainty. This makes the role of university copyright policies to clarify the situation even more critical. The remainder of this paper undertakes an analysis of these policy documents to assess whether and how they are performing this role.

\subsection{Previous studies of copyright policies}

A small number of studies of copyright policies have been undertaken, driven by a variety of motivations. Monotti and Rickeston (2003) undertook a study of copyright policies in the UK, US and Australia to inform their important overview of the Universities and intellectual property. The findings are thematic not quantitative, however they found that "the tradition within all countries was generally to make claims to ownership of copyright in [course materials] only when it was specifically commissioned, or created under an express contract". However, there was much variation amongst the individual UK universities studied.

In the US, there have been a series of quantitative studies of university copyright policies using a similar methodology that demonstrate changing attitudes towards copyright ownership over time. In 1992, Lape performed the first study of its kind of 42 public and private Carnegie Doctoral Research-Extensive Universities. Packard (2002) repeated the study in 2002 and Kromrey et al. (2007) ran it again in 2005, this time adding in some analyses particularly relating to teaching materials. They discovered a growing trend towards employers disclaiming the rights in scholarly works $(23 \%$ in 1992 , to $71 \%$ in 2002 and $93 \%$ in 2005) which directly correlated with a trend towards expressing commitment to academic freedom (26\% in 1992, to $42 \%$ in 2002 and $74 \%$ in 2005). Kromrey et al. (2007) reported that courseware was included in the definition of scholarly works in $40 \%$ of policies and in $36 \%$ of policies universities claimed they owned the rights in courseware and distance learning materials.

In 2008, Marshall performed a study of the copyright policies of 22 New Zealand HE institutions as they related to e-learning, and cross-tabulated the results by the type (university or polytechnic) of institution. He found that only $14 \%$ of university policies covered materials created for use in online or distance education $(29 \%$ of universities and $7 \%$ of polytechnics), and only $5 \%$ covered ongoing use of materials by employees 
after leaving the institution (none were polytechnics). However, $23 \%$ of policies covered ownership of materials created by academic visitors and non-employees.

In the UK, Davies (2015) investigated the approaches of UK universities towards academic freedom by studying 81 UK university copyright policies as they related to teaching materials. He found that $20 \%$ of policies allowed academics to "retain copyright in all materials, usually with an accompanying licence benefitting the university with regard to some teaching materials"; $25 \%$ of policies asserted "institutional copyright over teaching materials, but grant[ed] a licence to the academic originator for future use", however the largest proportion, 55\%, of policies asserted institutional copyright without any accompanying licence to academic staff. Other UK copyright policy studies such as those by Weedon (2000), and Rahmatian (2014) did not explicitly cover the copyright issues relating to teaching materials.

\section{Methods adopted}

To better understand UK universities' policy approaches towards teaching and elearning materials, a study of copyright policy documents was made. The 130 members of the Universities $U K$ (UUK) (2015) were chosen as the population. However, as Harvey (1996) has noted, obtaining a representative sample of IP policy documents is problematic due to the many and varied origins of UK universities. The approach to sampling was therefore to identify as many copyright policies as possible, even though this would result in a non-probability sample. Web searches were undertaken between February and April 2015 in an attempt to identify copyright policies. Where a copyright policy formed a clearly identifiable part of a set of University Regulations, Research Code of Practice or Staff/Student Handbook, these were also used for analysis. Where there was not sufficient information to a form a complete picture of the university's copyright ownership position, such documents were discounted for the purposes of this study. Where a document clearly referenced another openly available document that explicitly formed part of the university's overall approach to copyright ownership, this was included in the analysis.

Where a policy was not locatable, a message was sent to the principal UK university email discussion list for copyright matters, LisCopyseek (2015) to solicit the help of members in locating copies of such closed or unlocatable copyright policies. In retrospect, it is recognised that Freedom of Information Requests could have been made to universities with closed policies in order to get a wider sample.

Once the policies were identified, copies were saved to create a static reference point. This was thought to be particularly important in the case of web pages which are easy to update without a noticeable date change on the web site. A content analysis was performed manually on the documents identifying the occurrence of key terms and concepts, and the context in which they were used. The key terms and concepts were:

- Ownership of internal teaching materials

- Ownership of e-learning (or distance) teaching materials

- Ownership of performances

- Ownership rights of non-employees

- Rights on termination of contract 


\section{Findings}

\subsection{Policy availability and mission groups}

Policy documents were discovered for 97 of the 130 UUK members (74\%). However, 16 of these referred only to the copyright ownership of students. Another two were too brief to analyse. However, a further two 'closed' policies were obtained directly from the university, making the total number of staff policies analysed $81(62 \%)$. (The fact that Davies (2015) also performed his analysis on 81 policies is a coincidence and there is no way of knowing whether they belonged to the same institutions.)

Many UK universities are part of 'mission groups' which, as the name suggests, share common institutional goals. Of the $81 \mathrm{UK}$ university policies analysed, 48 were members of mission groups and were coded accordingly to allow for comparisons (see Table 1):

As the numbers in each mission group were fairly low, the universities in the GuildHE, Million +, and University Alliance groups were grouped together as they all serve the newer, more business-facing universities. Universities not belonging to any mission group were denoted as 'non-aligned'.

\subsection{Age of copyright policies}

It was not possible to determine the age of 13 policies but for the remaining 68 , the spread of copyright policy ages can be seen in Fig. 1, broken down by mission group. It can be seen that some policies had not been updated for over a decade, however the median age was 2010 . The median age of a copyright policy belonging to the new and unaligned universities was 2010, whereas the median age of a Russell Group copyright policy was 2013 .

\subsection{Ownership of copyright in teaching materials}

This and the following sections are based on the policies of 70 universities. This is because three of the initial 81 policies were concerned only with either patents or research-related rights and a further eight policy documents made no mention of

Table 1 Mission groups of the Universities studied

\begin{tabular}{|c|c|c|c|c|}
\hline Mission Group & $\begin{array}{l}\text { Classification } \\
\text { for the study }\end{array}$ & Description & $\begin{array}{l}\text { Total } \\
\text { membership }\end{array}$ & $\begin{array}{l}\text { Number included } \\
\text { in sample (\% of } \\
\text { total membership) }\end{array}$ \\
\hline Russell Group & Russell Group & $\begin{array}{l}\text { Large, research-intensive universities, } \\
\text { usually ancient or 'red-brick' }\end{array}$ & 24 & $18(75 \%)$ \\
\hline $\begin{array}{l}\text { University } \\
\text { Alliance }\end{array}$ & 'New' universities & $\begin{array}{l}\text { Business-facing modern universities } \\
\text { for the cities and regions }\end{array}$ & 18 & $14(77 \%)$ \\
\hline Million + & 'New' universities & New universities & 14 & $12(85 \%)$ \\
\hline Guild HE & 'New' universities & Former HE colleges & 28 & $4(14 \%)$ \\
\hline Not aligned & Non-aligned & $\begin{array}{l}\text { Ex-1994 Group institutions } \\
\text { and others }\end{array}$ & NA & 33 \\
\hline
\end{tabular}




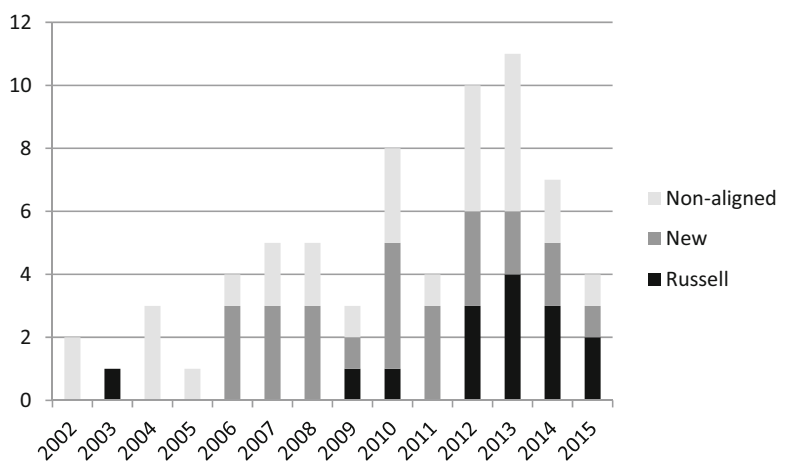

Fig. 1 Copyright policy dates by mission group

teaching materials (either internal or for e-learning use) whatsoever. This is despite the fact that ten years has passed since the HEFCE issued their guidance in 2006. This may be the consequence of long and complex negotiating periods around teaching materials ownership as suggested by Rahmatian (2014) or an assumption that teaching materials will be covered by a general reference to 'scholarly works'.

The literature shows a divide in opinion as to who should own the copyright in teaching materials. This analysis identified a wide range of ownership positions expressed in a variety of terminology relating to both internal and e-learning materials (see Fig. 2). To understand the implications of these varying positions, the data have been simplified in Fig. 3 to show, according to the policies, where ownership is purported to lie, and where control ultimately rests as a result of the waiving, assigning or licensing of rights. To clarify, a licence provides the licensee with written permission to make some use of the intellectual property but ownership rests with the licensor; this has been classified as shared ownership in the analysis as both parties are able to exercise rights over the work. An assignment is where the rights are handed over to the assignee, making them the sole rightful owner and a waiver is where the HEI disclaims any rights in the first place; both of these cases have been classified as staff ownership as the university chooses not to exercise any rights over the work. Some have questioned whether it is actually possible to "waive" copyright. Rahmatian (2014) concludes that "the legal assessment of a "non-assertion of copyright" clause... is a complicated matter for the lawyer".

\subsection{Internal teaching materials}

The majority of universities (54/70 or $77 \%$ ) make an initial claim to the ownership of copyright in internal teaching materials. This was considerably higher than Kromrey et al.'s (2007) finding in the US where only $36 \%$ made such a claim. Perhaps what is more interesting is that the other $16(23 \%)$ make no such claim. However, as Fig. 2 shows, not all universities making an initial claim to ownership then go on to retain those rights. Four universities license their rights, one assigns, and one waives, in favour of academic staff. A further two universities waive their rights but expect staff to licence them back. However, there are expectations in the opposite direction as $5(6 \%)$ of universities state that staff are the initial owners of the copyright in teaching materials, but expect them to license (4) or assign (1) some or all rights back to the 


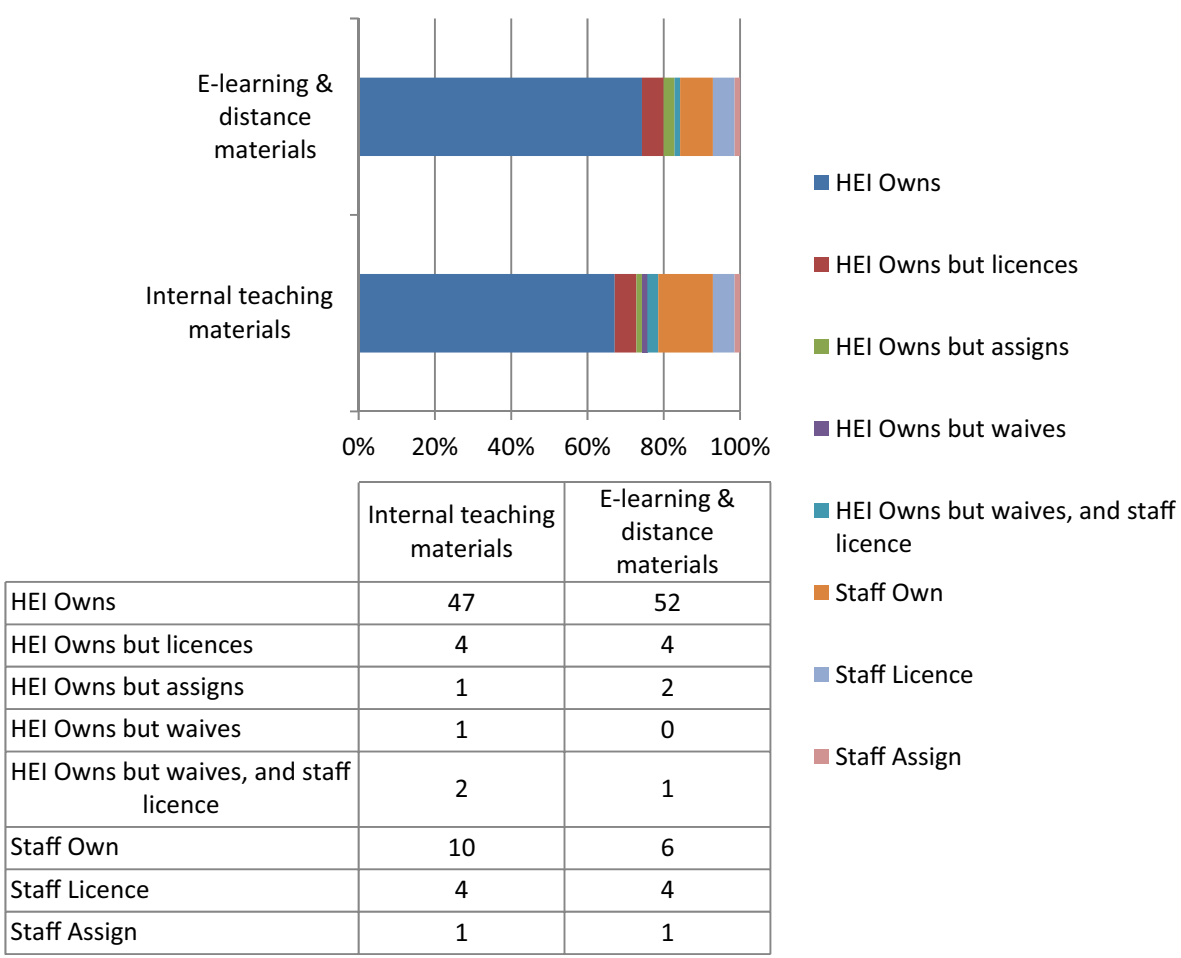

Fig. 2 Copyright ownership claims over teaching materials

university. As Fig. 3 shows, on balance, 48 (69\%) universities become eventually the guardian of the copyright in internal teaching materials, even if they do not claim to be the initial owner. In ten (14\%) cases there is some shared ownership by virtue of either the university owning rights and licensing some back to staff (4), or the staff member owning the rights and licensing them back to the university (6). It is interesting that the latter is more common than the former.

A cross-tabulation of the ultimate rights-holders of internal teaching materials with the median policy date and mission group of universities was performed. The median date of a policy in which universities claimed ownership of teaching materials was

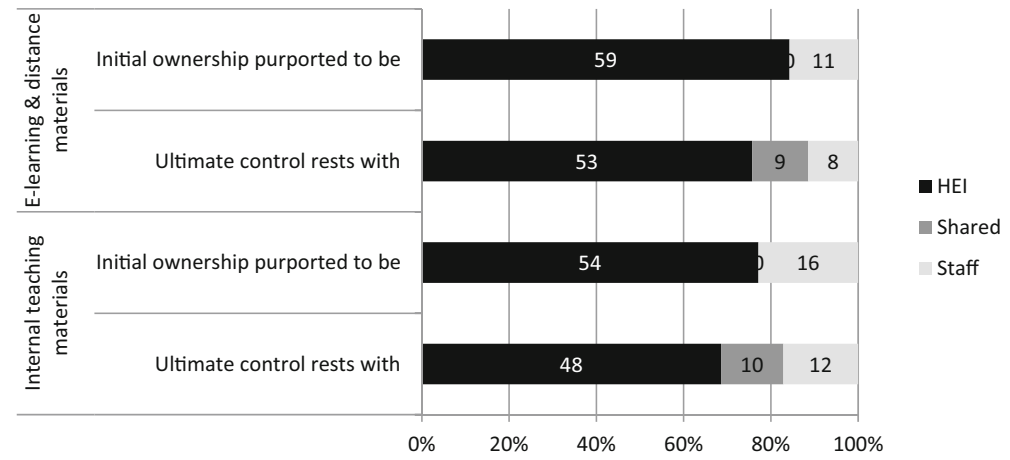

Fig. 3 Ultimate rights-holder or licensee in teaching materials 
2010 and the median date of policies in which universities relinquished rights to staff was 2012. Where the rights were shared between the two parties the median policy date was 2013. The policies not addressing this issue were the oldest of all with a median policy date of 2008 .

Figure 4 shows the mission groups of the universities holding various copyright policy positions on internal teaching materials. The data show that of the eight policies which shared ownership, the majority (5) belonged to the Russell Group. Of the 27 new universities, 25 (92\%) claimed ownership of internal teaching materials for the HEI.

\subsection{Teaching materials for distance or e-learning courses}

Figures 2 and 3 indicate a slight difference in approach taken by universities towards the potentially more commercially valuable copyright within e-learning or distance learning materials. In such cases, a higher proportion of universities (59 or 84\%) claim outright ownership of copyright, and a higher proportion (53 or 76\%) are the ultimate rights-holder. Shared ownership of this category of materials is also slightly lower with only nine policies $(13 \%)$ specifying some form of licensing arrangement. However, a Chi-Square test showed that the difference between the ultimate ownership positions taken by universities' towards their internal and e-learning materials was not statistically significant.

The median age of the policies adopting the various rights-holder positions follows an identical pattern to those relating to internal teaching materials (see above).

By comparing Figs. 4 and 5, it is immediately apparent that the differences in policy approach taken by the various mission groups towards internal and e-learning materials are minor. Indeed, the new universities adopt the same approach towards both types of material. The differences are to be seen amongst the Russell Group members and the unaffiliated universities where three more of each claim ownership of e-learning materials for the HEI.

\subsection{Teaching performances}

The HEFCE guidance (2006) stated that "contracts of employment with staff should make clear that they own the performers' rights in any video or other recording of their own lectures or presentations". In fact, only 16 of the 81 policies $(20 \%)$ included in this

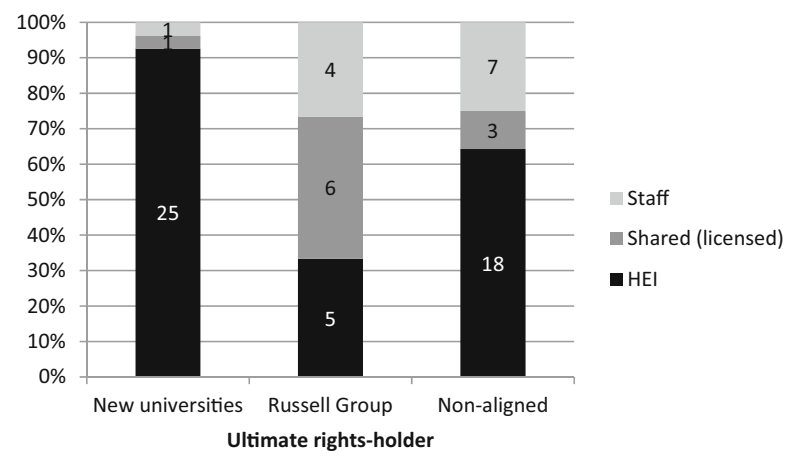

Fig. 4 Ultimate rights-holders of internal teaching materials by mission group 


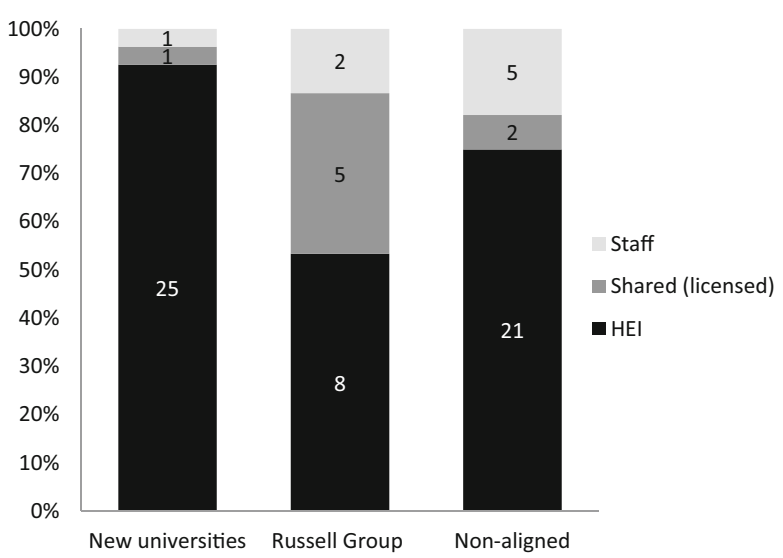

Fig. 5 Ultimate rights-holders of distance and e-learning materials by mission group

study made any mention of teaching performances in their copyright policies. Of the 16 , ten stated that academic staff are the rightful owners, however four of these then require staff to license performance rights to the university. One university specified that a licence was only required from staff in order for them to comply with the "Disability Discrimination Act" for the provision of recordings to students with additional needs. The remaining six universities (incorrectly in law) claim ownership of performances for themselves. Two of the latter may not have intended to do so, but they list performance rights as a form of IP in their definitions, make a general claim to the ownership of all IP produced by employees, and then fail to make any other provisions for performance rights.

\subsection{Rights ownership by non-employees}

The HEFCE guidance (2006) encouraged universities not only to assert ownership of the IPR in e-learning materials created by staff, but also by "freelance, and where agreed by them, [...] student creators." An examination of the copyright policies included in this study revealed that less than half (37 or 46\%) made reference to the rights ownership situation relating to non-employees. This needs to be considered in light of the fact that some copyright policies are expressed in staff conditions of service documents, and therefore would not be expected to cover rights relating to non-staff. This figure is considerably higher than the $23 \%$ of New Zealand university policies that were found to address this matter (Marshall 2008).

\subsection{Ownership of teaching materials on termination of contract}

Monotti and Rickeston (2003) and Weedon (2000) both report that academics expect to be able to take at least a copy of their teaching materials with them if they move to another place of employment. Of the 70 policies studied, $36(51 \%)$ made no reference to what would happen to the ownership of IP in teaching materials after staff left the institution. In 29 cases this may have been because the university asserted ownership of copyright and so felt they needed to make no 
further provisions. The remaining 34 (49\%) did state their position on the ownership of IPR once staff have left. Figure 6 outlines the four main positions taken, broken down by mission group.

It can be seen that in most cases, either the university claims the right to use teaching materials after the staff member has left (11 policies), or staff ownership rights expire on leaving the university (10 policies). The former includes three cases where the statement refers to all copyright so that teaching materials are included by default. The latter includes two cases where rights are only asserted by the university in some cases, and therefore only expire for those cases when an author leaves, and three cases where rights expire but continuous use of teaching materials could be negotiated by the staff member, as suggested by the HEFCE guidance. Essentially, in the majority of cases (two-thirds), where the university makes reference to the copyright ownership of teaching materials after the employee has left, it is to assert their own right to continued use of those materials. In the remaining third, the policy offers staff a licence to continue to use teaching materials they have co-authored after they have left the institution. In seven cases, this right is without restriction; in four cases only noncommercial use is allowed.

The mission group cross-tabulation showed that no new university licensed staff to re-use their teaching materials after they had left the institution. Similarly, no Russell Group policy stated that the rights of staff to use their teaching materials expired on termination of contract. An analysis of the median policy dates of policies adopting the positions outlined in Fig. 6 showed that where staff were offered a licence to use the teaching materials, the median policy dates were more recent (2012-2013) compared to where staff rights were said to expire on termination of contract (2009) or where the university claims rights to use the teaching materials (2007).

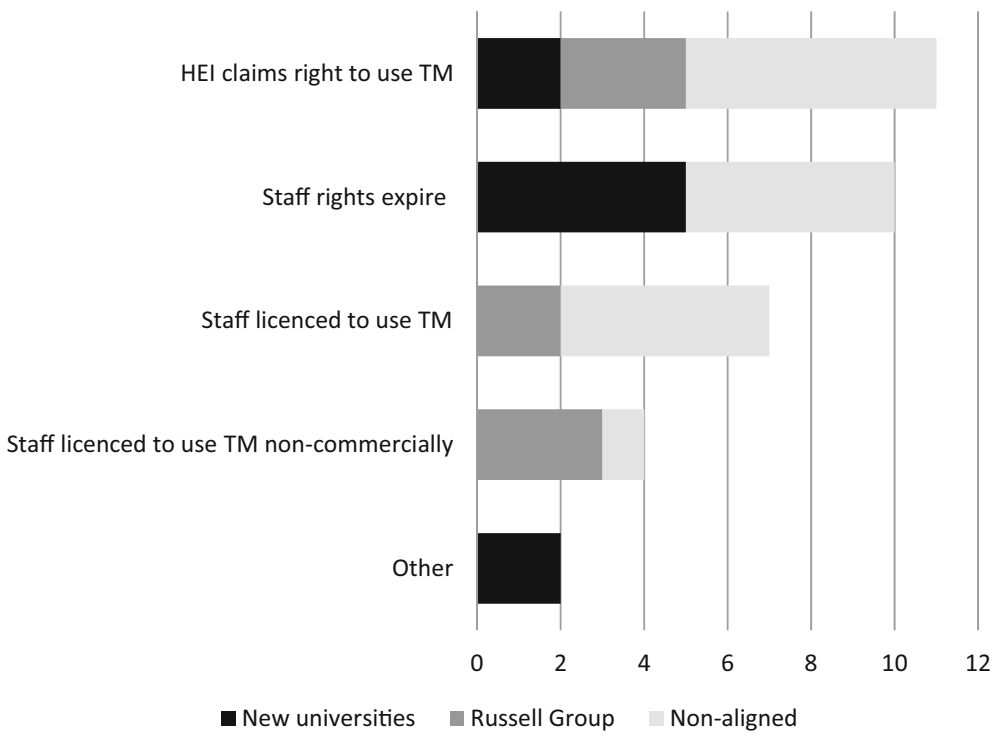

Fig. 6 Policy position on copyright ownership of teaching materials (TM) on termination of contract 


\section{Discussion and recommendations}

\subsection{Copyright ownership of teaching and e-learning materials}

This analysis shows that the majority of UK university copyright policies specifically address the rights ownership of teaching and e-learning materials, although $10 \%(8 / 81)$ of policies - mainly older policies - do not do so. In the majority of cases, the policies state that the ownership of both internal $(77 \%)$ and distance or e-learning materials $(84 \%)$ rests with the university. However due to the number of policies that waive, assign or license rights, the proportion of universities retaining ultimate control of these materials is reduced to $69 \%$ for internal teaching materials and $76 \%$ for distance and elearning materials. Whilst these differences are not statistically significant, they suggest that universities view e-learning materials differently to internal teaching materials in intellectual property terms.

Whilst UK university copyright ownership policy positions towards teaching materials aligns with the guidance proffered by HEFCE (2006), it is at odds with the views and expectations of academic staff. UK scholars (Pila 2010; Rahmatian 2014; and Davies 2015) all make a strong case for, if not academic ownership, at least shared ownership. In fact, only 10 of the 70 (14\%) UK copyright policies analysed offered some form of shared ownership via licensing for e-learning materials (nine out of 70 for internal teaching materials). That said, the policies that took a shared ownership position towards teaching and e-learning materials had later median policy dates than those where the university claimed ownership. This may indicate a trend towards the sharing of rights in teaching and e-learning materials. It would be interesting to keep a watching brief on this over time to see if a trend develops.

\subsection{Coverage of non-employees}

The literature reminds us that academic staff are not the only contributors to the development of teaching materials, particularly distance or online materials. It was surprising therefore that, even making allowance for the fact that some of the documents identified were part of staff conditions of service, and so related specifically to staff, less than half the UK copyright policies made reference to the copyright owned by non-staff. Even if universities do not go as far as the recommendation of the HEFCE (2006) guidance and claim the copyright of "freelance and (where agreed by them) student creators", it is important for UK universities to consider their position on this. A more in-depth study of UK copyright policy approaches towards students would be timely in this regard.

\subsection{Coverage of performances}

After literary works, performances are probably the most important category of copyright work relevant to a study of the rights in e-learning materials. The fact that this category of materials is only covered by $20 \%$ of copyright policies is therefore something of a concern, as is the further fact that over one-third of these universities claim the copyright in performances for themselves. Any institution with 
expectations around the recording and reuse of academic teaching performances would do well to negotiate the right to do so and make the rights situation explicit in their copyright policy.

\subsection{Rights on termination of contract}

In a similar way, just over half of the policies (51\%) did not address the ownership of copyright when academics terminate their contracts. A number of scholars have used the mobility of academic staff as an argument for the need for academics to retain copyright in their teaching materials (see Levin 2000). Such claims are legitimised by the lack of reference in copyright policies to the rights academics have over their teaching materials when they leave the institution. Where policies did express a view on this, it was usually to assert the university's right to continued use of those materials, rather than an attempt to guarantee academics' rights. Few would argue with a university's claim to re-use the teaching materials an academic creates whilst in employment. However, most would also see an academic's claim to re-use the teaching materials they had created at a subsequent place of employment as equally legitimate. They would also accept an academic's right to continue to be acknowledged as the intellectual originator of those teaching materials. A handful of policies have struck this balance. It is recommended that more universities do so.

An issue that is pertinent here, but out-with the scope of this particular study, is whether universities actually police their copyright policies with regards to rights on termination of contract (or indeed any other clause). Such cases are most likely to be settled before coming to court, however, a survey of the experiences of academic staff that have recently moved institution would make an interesting study. If, as expected, universities do not in practice enforce their copyright policies in this regard, it begs the question as to why they put them in place at all.

\subsection{The effect of policy age and mission group}

Where cross-tabulations with the age of the policy and the mission group of the organisation were performed, some differences were observed, however the numbers were not large enough to perform any meaningful statistical analysis. Looking at the policy approaches towards the ownership of internal and e-learning materials, more Russell Group members had policies in which rights were shared through licensing. By contrast, new universities were more likely to assert ownership over both forms of content. However, both groups were slightly less liberal towards the ownership of elearning materials than they were towards the ownership of the potentially less commercially valuable internal materials - as were non-aligned universities. Interestingly, a similar pattern was found with regards to rights on termination of contract: no Russell Group policy stated that the rights of staff to use their teaching materials expired on termination of contract, and no new university licensed staff to re-use their teaching materials after they had left the institution. This is probably indicative of the new universities' more business-like approach towards education. However, it may also be symptomatic of the willingness of Russell Group organisations to adopt more liberal policies in an effort to attract the best scholars. 
It was interesting to note that the median age of a Russell Group copyright policy was three years more recent that a new university copyright policy. This may have had a bearing on the cross-tabulations relating to policy age which showed that the newer the policy, the more liberal it was. In fact there was a three year gap between the median policy dates of universities asserting ownership of e-learning and teaching materials, and those where some form of shared approach via licensing was in place. This might be a promising sign. As others have noted, it is the larger, more established universities that tend to lead the way with best practice in areas of copyright policy (Kiskis 2012). If the most recent policies adopted by the larger universities are starting to address some of the key issues in a balanced way, this can only be a promising sign for the rest of the sector.

\section{Conclusions}

Undoubtedly, the ownership of rights in both internal teaching and e-learning materials in UK universities is complicated and contentious. However, the growth in e-learning activity means that it is more important than ever that these issues are resolved and clarified through a university's copyright policy. Clearly, all parties have legitimate interests and the organisations which manage to have an open dialogue about those interests are most likely to reach a satisfactory conclusion that benefits everyone. Adopting a pragmatic approach whereby one party licenses the other with the rights they require would seem to be the best way forward, and one that is starting to be adopted by newer copyright policies, and the larger, more established UK universities.

Universities should keep their copyright policies under regular review in partnership with academic staff and other players, and that those institutions investing in any form of e-learning should seek to ensure that their policies towards the ownership of rights in performances; by non-employees; and by staff on termination of contract are adequately documented. To this end, universities would be greatly assisted by a sector-wide agreement on the rights and re-use requirements of all parties involved in the creation of e-learning materials. HEFCE's Intellectual Property Rights in E-learning Programmes guidance sought to provide this through a model licence. However, this has not been wholly adopted by the sector, perhaps because it was seen to represent the interests of universities over academics. A decade after the original guidance was published, it might now be timely for a multi-stakeholder reconsideration of some of its advice to serve better the needs of all parties involved in the creation of e-learning materials in UK universities.

Open Access This article is distributed under the terms of the Creative Commons Attribution 4.0 International License (http://creativecommons.org/licenses/by/4.0/), which permits unrestricted use, distribution, and reproduction in any medium, provided you give appropriate credit to the original author(s) and the source, provide a link to the Creative Commons license, and indicate if changes were made.

\section{References}

Association of University Teachers (1999). Your guide to intellectual property rights. Available at: http://www. ucu.org.uk/media/pdf/e/6/iprguide_aut_19991.pdf. 
Bates, M., et al. (2007). Attitudes to the rights and rewards for author contributions to repositories for teaching and learning. Alternatives Journal, 15(1), 67-82 Available at: http://www.tandfonline. com/doi/abs/10.1080/09687760600837066.

BIS (Department for Business Innovation and Skills) (2013). The maturing of the MOOC, Available at: https://www.gov.uk/government/uploads/system/uploads/attachment_data/file/240193/13-1173maturing-of-the-mooc.pdf.

Blanchard, J. (2010). The teacher exception under the work for hire doctrine: Safeguard of academic freedom or vehicle for academic free enterprise? Innovative Higher Education, 35, 61-69.

Bowrey, K. (2002). The ideal copyright framework for academic authors? A bounty to genius and learning. AARL. Australian Academic \& Research Libraries, 33(4), 37-41 Available at: http://alia.org. au/publishing/aarl/33.4/full.text/bowrey.html.

Cate, B., Drooz, D., Hohenberg, P., \& Schulz, K. (2007). Creating intellectual property policies and current issues in administering online courses. Paper presentation, NACUA meeting, San Diego, CA, November 7-9, 2007.

Centivany, A. (2011). Paper Tigers: Rethinking the Relationship Between Copyright and Scholarly Publishing. Michigan Telecommunications and Technology Law Review, 17(2), 385.

Cheverie, J. (2013). Copyright challenges in a MOOC environment. Educause. Available at: https://net. educause.edu/ir/library/pdf/PUB9014.pdf.

Copyright, Designs and Patents Act. (1988). C., 48 .Available at: http://www.legislation.gov.uk/ukpga/1988 $/ 48 /$ section/163

Davies, M. (2015). Academic freedom: a lawyer's perspective. Higher Education, 70(6), 987-1002 Available at: http://ink.springer.com/10.1007/s10734-015-9884-8.

Gadd, E., Oppenheim, C., \& Probets, S. (2003). RoMEO studies 1: the impact of copyright ownership on academic author self-archiving. Journal of Documentation, 59(3), 243-277.

General Revision of the Copyright Law of the United States Code (1976). Title 17, Chapter 2, s 102(b). See here for 'Works Made for Hire': https://www.copyright.gov/title17/92chap2.html.

Gertz, G.A., 2006. Copyrights in Faculty-Created Works: how licensing can solve the academic work-for-hire dilemma. 267(2004), pp. 1465-1493.

Halme, M., \& Somervuori, O. (2012). Copyrighted internet material in education-teacher needs and use arrangements. Education and Information Technologies, 17(3), 331-344.

Harvey, K. (1996). Capturing intellectual property rights for the UK: a crtitique of university policies. In A. Webster \& K. Packer (Eds.), Innovation and the intellectual property system. London: Kluwer Law International.

Higher Education Funding Council for England (2006). Intellectual property rights in e-learning programmes. Available at: http://www.hefce.ac.uk/pubs/hefce/2003/03_08.htm.

Jisc (1998). Jisc/TLTP Copyright Guidelines. Available at: www.ukoln.ac.uk/services/elib/papers/other/jisctltp/jisc.pdf.

Kiskis, M. (2012). Faculty intellectual property rights in Canadian universities. Baltic Journal of Law and Politics, 5(2), 81-108.

Klein, M.W. (2005). Protecting Faculty Rights in Copyright Ownership Policies. In Annual Conference on Distance Teaching and Learning (pp. 1-5). Available at: http://www.uwex.disted/conference/.

Kolowich, S. (2013). Professors who make the MOOCs. Chronicle of Higher Education. Available at: http://chronicle.com/article/The-Professors-Behind-the-MOOC/137905/\#id=overview.

Kromrey, J., Barron, A., \& Hogarty, K. (2007). Intellectual property and online courses: policies at major research universities. Quarterly Review of Distance Education, 8, 109-125.

Lape, L.G., 1992. Ownership of Copyrightable Works of University Professors: The Interplay between the Copyright Act and University Copyright Policies. Vill. Law Review, 37(2).

Levin, D. A. (2000). Who owns course materials prepared by a teacher of professor? The application of copyright law to teaching materials in the internet age. Brigham Young University Education and Law Journal, 2000(1), 1-20.

LisCopyseek. (2015). Lis-Copyseek Discussion List. .Available at: https://www.jiscmail.ac.uk/lists/LISCOPYSEEK.html

Literat, I. (2015). Implications of massive open online courses for higher education: mitigating or reifying educational inequities? Higher Education Research \& Development, 4360, 1-14 Available at: http://www. tandfonline.com/doi/full/10.1080/07294360.2015.1024624.

Loddington, S. et al. (2006). Copyright ownership of teaching materials. Available at: https://dspace.lboro.ac. uk/dspace-jspui/bitstream/2134/2702/1/CopyrightOwnership\%5b1\%5d.pdf.

Loggie, K. A., et al. (2006). An analysis of copyright policies for distance learning materials at major research universities. Journal of Interactive Online Learning, 5(3), 224-242. 
Longdin, L. (2004). Copyright Dowries in Academia: Contesting Authorship and Ownership of Online Teaching Materials in Common Law Jurisdictions. International Review of Intellectual Property and Competition Law, 35(1), 22-45.

Marshall, S. (2008). Copyright policy issues facing tertiary institutions engaged in e-learning. Hello! Where are you in the landscape of educational technology? Proceedings ascilite Melbourne 2008 (pp. 582-592). Available at: http://www.researchgate.net/publication/228601995_Copyright_policy_issues_facing_ tertiary_institutions_engaged_in_e-learning/file/e0b495241f8bd930b5.pdf.

Matkin, G.W.. (2006). The Open Educational Resources Movement: Current Status and Prospects, pp. 1-5. Available at: http://unex.uci.edu/pdfs/dean/matkin apru paper.pdf.

McCann, C. (2014). Employees: restraint of trade, Westlaw. Available at: http://westlaw.co.uk.

McSherry, C. (2001). Who owns academic work? Battling for control of intellectual property. Cambridge: Harvard University Press.

Monotti, A., \& Rickeston, S. (2003). Universities and intellectual property: ownership and exploitation. Oxford: Oxford University Press.

Newman, M. (2010). Hold on, that slide looks very familiar.... Times Higher Education, 20, 12.

Noble, D. F. (1998). Digital diploma mills: The automation of higher education. Science as Culture, 7(3), 355368.

Packard, A. (2002). Copyright or copy wrong: an analysis of university claims to faculty work. Communication Law and Policy, 7(3), 275-316.

Pila, J. (2010). Who owns the intellectual property rights in academic work ? European Intellectual Property Review, 609, 1-7.

Porter, J. E. (2013). MOOCs, "Courses," and the Questions of Faculty and Student Copyrights. CCCC Intellectual Property Annual, 8, 2-18.

Rahmatian, A. (2014). Make the butterflies fly in formation? Management of copyright created by academics in UK universities. Legal Studies, 34(4), 709-735.

Rhoades, G. (1998). Managed professionals: unionized faculty and restructuring academic labor. Albany: State University of New York Press.

Secker, J., \& Morrison, C. (2016). Copyright and e-learning (2nd ed.). London: Facet Publishing.

Strauss, N. (2011). Anything but academic: how Copyright's work-for-hire doctrine affects professors, graduate students, and K-12 teachers in the information age. Richmond Journal of Law \& Technology, XVIII, 1, 1-47.

University and College Union (2006). Post-92 Contract of Employment. Available at: https://www.ucu.org. uk/article/1972/Post-92-contract-of-employment. Accessed 12 Jan 2017.

University and College Union,[n.d.] Intellectual Property Rights. Available at: http:/www.ucu.org.uk/index. cfm?articleid=2386 [Accessed December 10, 2015].

Universities UK (UUK). (2015). Available at http://www.universitiesuk.ac.uk/. Accessed 31 Jan 2017.

Weedon, R. (2000). Policy approaches to copyright in HEIs. Jisc; Centre for Educational Systems and Technology, Stratchlyde.

Weinstein vs University of Illinois (1987). 811 F.2d 1091, 1093-94 (7th Cir 1987).

Williams vs Weiser (1969). 78 Cal Rptr 542 \& 273 Cal. App. 2d 726.

Zhang, K., \& Carr-Chellman, A. (2006). Courseware copyright: whose rights are right? Journal of Educational Computing Research, 34(2), 173-186. 